\title{
AGE OF Eucalyptus urograndis PLANTATIONS AND OCCURRENCE OF PEST INSECTS ${ }^{1}$
}

\author{
Joana Gabriela Freitas Andrade ${ }^{2}$, Verissimo Gibran Mendes Sá ${ }^{3}$, Sara Lodi ${ }^{4}$ and Bruno Spacek Godoy ${ }^{*}$
}

\footnotetext{
${ }^{1}$ Received on 03.06.2015 accepted for publication on 16.09.2016.

${ }^{2}$ Universidade do Estado de Minas Gerais, Graduada em Engenharia Ambiental, João Monlevade, MG - Brasil. E-mail: $<$ joanagabrielaster@gmail.com>.

${ }_{3}^{3}$ Dow AgroSciences, Ribeirão Preto, SP - Brasil. E-mail: <verisgibran@gmail.com>.

${ }^{4}$ Universidade Federal de Goiás, Mestrado em Ecologia e Evolução, Goiânia, GO - Brasil . E-mail: <lodi.sara@gmail.com>.

${ }^{5}$ Universidade Federal do Pará, Núcleo de Ciências Agrárias e Desenvolvimento Rural, Belém, PA-Brasil. E-mail: <bspacek@gmail.com>.

*Corresponding author.
}

\begin{abstract}
Eucalyptus species are originally from Australia and its plantations is the major forestry activity in Brazil. The Myrtaceae family is widely represented in Brazil, enabling native insects to migrate to Eucalyptus plants. Native herbivorous insects may adapt to the species planted in monoculture with low availability of their natural host plants and natural enemies. Within this context, the differential occurrence pattern of eleven insect pests of Lepidoptera, Coleoptera and Hemiptera orders, from 450 Eucalyptus stands of different ages recorded in 2002 to 2010 in eastern State of Minas Gerais, Brazil was evaluated. Bayesian inference was used for data analyses in hypothesis testing. The probability of occurrence of pest species was estimated using a linear multinomial model, relating their occurrence with the Eucalyptus stand age. Pest occurrence in Eucalyptus stands were linked to plant age, with younger ones being more susceptible to phytophagous insects. That association with chronological plant age may be associated with the resource exploration strategy of each group of pest insects. Thus, Eucalyptus forest management should be adapted to the temporally differential use of the stands by pest species, providing more efficient control strategies.
\end{abstract}

Keywords: Population ecology; Bayesian inference; Forestry pest management.

\section{IDADE DO PLANTIO DE Eucalyptus urograndis E A OCORRENCIA DE INSETOS PRAGAS}

\begin{abstract}
RESUMO - As espécies de Eucalyptus são originárias da Austrália e suas plantações são a principal atividade florestal no Brasil. A família Myrtaceae é amplamente representada no Brasil, permitindo que insetos nativos utilizem as plantas de Eucalyptus. Insetos herbivoros nativos podem se adaptar-se a espécies plantadas em monoculturas quando privados de suas plantas hospedeiras naturais e inimigos naturais. Nesse contexto, o padrão de ocorrência diferencial de 11 espécies de insetos pragas das ordens Lepidoptera, Coleoptera e Hemiptera, de 450 talhões de Eucalyptus de idades variadas, foi avaliado entre 2002 e 2010 no leste do Estado de Minas Gerais foi avaliado. A inferência bayesiana foi usada para análise de dados nos testes de hipóteses. A probabilidade de ocorrência das espécies pragas foi estimada usando um modelo multinomial linear, relacionando sua ocorrência com a idade do talhão de Eucalyptus. A ocorrência das pragas nos talhões de Eucalyptus foi relacionada à idade da planta, observando-se que talhões mais jovens foram mais suscetiveis à insetos fitófagos. Essa associação com períodos cronológicos da planta pode estar associado às estratégias de exploração que cada grupo de insetos praga apresenta. Assim, o manejo de florestas de Eucalyptus deve ser adaptado com base no diferencial das espécies pragas no talhão, gerando estratégias mais eficientes de controle de pragas.
\end{abstract}

Palavras-chave: Ecologia de populações; Inferência Bayesiana; Manejo de pragas florestais. 


\section{INTRODUCTION}

Eucalyptus species, originally from Australia, represent the main forestry activity in Brazil (LARANJEIRO, 1994). The Brazilian states of Minas Gerais, São Paulo, Paraná, Bahia, Santa Catarina, Mato Grosso do Sul and Rio Grande do Sul hold $87.7 \%$ of the total area cultivated with eucalyptus. The major industries processing eucalyptus plants, like pulp and paper, wood panels, charcoal for metallurgy and mechanically processed wood are located in those states (ABRAF-ASSOCIAÇÃOBRASILEIRADEFLORESTAS PLANTADAS, 2011).

Myrtaceae family, which Eucalyptus belongs, is well represented with a high number of native species in different regions and biomes of Brazil (LEITÃO FILHO, 1987). Consequently, the Eucalyptus species introduced in this country for forest management are been used as resources by native insects (STRONG et al., 1984; SANTOS et al., 1996; HOLTZ et al., 2003). The number of phytophagous insects of different orders is elevated the tropical region (JANZEN, 1970; CONNELL, 1971; CLARK; CLARK, 1984; SUTTON; COLLINS, 1991; CORNELL; HAWKINS, 2003). Once deprived of their natural host plants and predators, native herbivore species, with low pressure from natural enemies and scarce native host plants may adapt to species planted in monoculture, becoming pests (VALENCIA; ATKINSON, 1987; ZANUNCIO et al., 1993a).

The genera Euselasia, Glena, Thyrinteina (Lepidoptera), Heilipodus, Costalimaita, Psiloptera and Lampetis (Coleoptera) are among the main native insect pests as defoliators and borers in Eucalyptus spp. plants in Brazil (BERTI-FILHO, 1981; ZANUNCIO et al., 1989; ZANUNCIO et al., 1993b). Larvae of defoliators (usually Lepidoptera as moths and butterflies) feed on the leaf surface and thus reduce the photosynthetic capacity of plants. Coleoptera larvae (beetles) are woodborers digging galleries into tree trunks. This behavior causes branches and tree trunks to break, reduce shoot growth, and depreciate the wood. Therefore, knowledge of pest dynamics may contribute to the management of eucalyptus plantations and thus reducing costs of pest control and increasing the commercial value of the products.

The spatial distribution of species and the physiological condition of the host are two independent factors determining the joint population dynamics of

Revista Árvore, Viçosa-MG, v.40, n.5, p.885-892, 2016 host and pests (SIVA-JOTHY et al., 2001; AGOSTA, 2006). The spatial factor effect on pest occurrence patterns in forestry systems present low variation because crop sites are usually environmentally homogeneous (WILSON; BJORNSTAD; DOBSON, 2002). On the other hand, plantation age may determine pest occurrence because structural and physiological changes occur in the plants during aging specially accumulation of secondary products (ZANUNCIO et al., 1998; GUREVITCH et al., 2009). These products are a defense mechanism against herbivores and may turn plant tissues unpalatable or even damaging consumers (KARBAN et al., 1999).

Phytophagous species are be restricted by the concentrations of defensive secondary products (FOWLER; LAWTON, 1985) and biological control (BRAGANÇA et al., 1998; PEREIRA et al., 2008). This specialization would lead pest insect species to be associated with plants of specific ages, a resource available during a particular plant development period, what is associated with secondary product concentrations. The hypothesis that Eucalyptus urograndis plantations age influences the occurrence of different pest species was tested.

\section{MATERIALAND METHODS}

\subsection{Study area}

Eleven previously established Operational Taxonomic Units (OTU, characterized respectively by seven morphospecies and four species) of pest insects recorded from 2002 to 2010 were used. The study area comprised 450 eucalyptus commercial stands averaging 25 hectares each and with different ages in the eastern region of Minas Gerais, Brazil (Figure 1). The climate of this region is Aw (FINLAYSON; MCMAHON, 2007), with average annual temperature of $21.6^{\circ} \mathrm{C}$ and average annual precipitation of $1256.5 \mathrm{~mm}$ (INMET, 2011). The E. urograndis stands age ranged from five to 170 months comprising plantations with variations in physical and chemical properties (such wood hardness and secondary composts accumulation) and tree trunk anatomy (different disposal of canopy tree). Teams roamed the plantations weekly seeking signs of damage on plants and recording pest occurrence. Insects were sampled and identified, after herbivory was detected. Local control practices were applied depending on the damage extension intensity, 
using chemical defensives only in the affected trees. However the chemical control was rarely used in the occurrence of pest insects (lesser than $5 \%$ of cases), wherein the large portion of cases the pest outbreaks was naturally controlled.

\subsection{Data analysis}

The hypothesis was tested using Bayesian inference, once it is more efficient to estimating parameters in more complex systems without previously established likelihood distributions (ANDRADE; KINAS, 2008). The credibility intervals (CI; 95\%) for the parameters of interest were calculated using Monte Carlo Markov Chains, and directly used to test hypothesis (PAULINO et al., 2003). The CI values correspond to an interval in which the real parameter has a high probability of occurring. The parameters were the relationship between pest occurrence and plantation age (GELMAN et al., 2003; ANDRADE; KINAS, 2008).

The probability of pest species occurrence was estimated with a multinomial linear model, which relates the pest species occurrence with eucalyptus stand age. The analytical model used was: $O\left(x_{1}, x_{2}, \ldots, x_{\mathrm{i}}\right) \sim$ Multinomial $(P[1,2, \ldots, i])$, with $\mathrm{P}(i) \sim \operatorname{Beta} G(\alpha, \beta$, age $), \alpha \sim \operatorname{Gamma}(0.001,0.001)$ and $\beta \sim \operatorname{Gamma}(0.001,0.001)$. In the model $O\left(x_{1}, x_{2}, \ldots, x_{i}\right)$ is the vector of occurrences of the $i$ OTU of eucalyptus pests in a stand, $\alpha$ and $\beta$ the parameters of a generalized

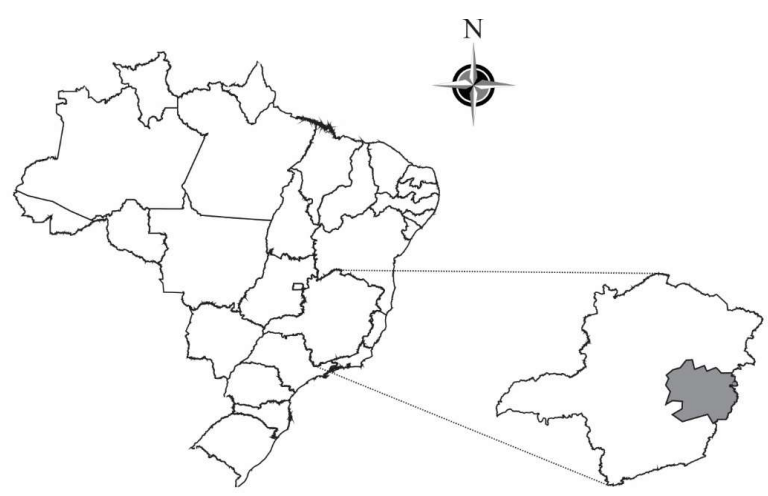

Figure 1 - Area of study. The 450 Eucalyptus urograndis stands are throughout the area highlighted in gray on the map.

Figura 1 - Area de estudo. Os 450 talhões de Eucalyptus urograndis estão distribuídos na área destacada em cinza no mapa.
Beta function (BetaG) for the relation between plantation age and the probability of the occurrence of pest $i$, in the age interval of five to 170 months. Both parameters had a non-informative prior distribution (gamma distribution with parameters $a$ and $b$ of 0.001$)$. The $\mathrm{R}^{2}$ values were calculated for each OTU individually, using the result of the Beta function, and an estimated the model fit for each organism studied was obtained.

The pest OTU into three categories was grouped for a better result interpretation. These categories were related to stand age where the OTU had higher probabilities of occurrence (Table 1). The groups were, the initial, middle and late OTU found in stands up to 24 months, 24 to 100 months over 100 months since the plantation. These groups did not fixed in the Eucalyptus stands, because the observation of tree damage in the study area was occurred in eight years, a time period enough to a young stand become a mature commercial forest. So, a stand with little age ( $>24$ months) had and controlled outbreak in the past, may be an object to future outbreaks in most advanced age in the observed time period.

\section{RESULTS}

The eleven main species and/or morphospecies of pest insects belonged to the orders Lepidoptera, Coleoptera and Hemiptera (Table 1). The total pest occurrence did not vary with eucalyptus plantations age, without higher pest occurrence adjusted to the age of observed stand (Figure 2). Thaumastocoris peregrinus (Hemiptera) occurred throughout the period, but their occurrence increased between the 45 and 100 months of stand age (Figure 3). Although the Costalimaita sp., Heilipodus sp., Glena sp. and Thyrinteina sp showed peaks of outbreaks (elevated occurrence probabilities related to stand age), they had a lower number occurrences in the period studied (10, 11, 3 and 2 occurrences for each OTU respectively). The species Euselasia eucerus, Nystalea nyseus, one morphospecie of Coleoptera, Lampetis sp. and Psiloptera $\mathrm{sp}$. had higher probability of occurrence in the initial plantation stage but they had a lower incidence (from the fifth to the 24th month, Figure 3 ). The occurrence of Salubodes caberata in eucalyptus plantations peaked in the initial stage and increased 65 months after planting (Figure 3 ).

Revista Árvore, Viçosa-MG, v.40, n.5, p.885-892, 2016

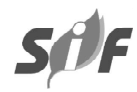


The model adjusted to the species was overall high, with $\mathrm{R}^{2}$ values above 0.90 (Table 1). Species with low model adjustment were not considered on the discussion, namely Glena $\mathrm{sp}$. and Thyrinteina $\mathrm{sp}$. $\left(\mathrm{R}^{2}\right.$ values of 0.29 and 0.17 respectively). A total of $77 \%$ of the species occurred in the initial plantation periods and outbreaks occurred mainly before 55 months of planting (Table 2 and Figure 3). Thaumastocoris peregrinus and $S$. caberata were the only species that an increase in outbreak probability in middle-aged plantations. No outbreaks of OTU were recorded in older plantations.

The overall pattern for the OTU showed that the Coleoptera had higher probabilities of outbreak in the initial plantation period. On the other hand, the Lepidoptera OTU had higher occurrence in the intermediary age period. The Hemiptera observed

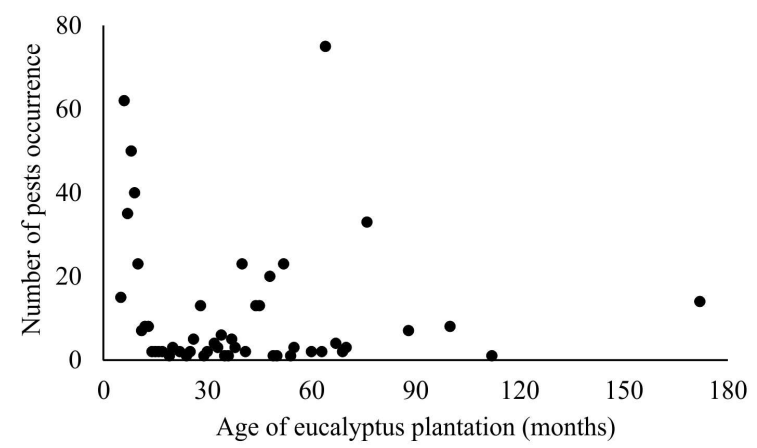

Figure 2 - Total occurrence of pests in the study period. Figura 2-Ocorrência de todas as pragas no período de estudo. occurred mainly in intermediary ages but its presence was found until older plantation ages (Table 2 and Figure 3).

\section{DISCUSSION}

The occurrence of pests in Eucalyptus stands was linked to plant age with younger stands being more susceptible. Juvenile stage plants have variations mainly related to cell dimensions, cell wall organization and wood physical and chemical characteristics. Biomass incorporation rate begins to stabilize after 48 months, but it varies on rate of each plant (e.g., growth rate), which in turn depends on genetic, edaphic and climatic factors (TRUGILHO et al., 2009). Therefore, a lower concentration of secondary compounds is expected in younger individuals.

The different morphological and functional adaptations of pests to eucalyptus may explain their temporally differentiated occurrence. The habitat template theory posits that eco-physiological constraints of the organism guide population growth (SOUTHWOOD, 1977). Thus, physiological changes of plants during aging are the main environmental factor to which the pest species are subject to (GUEDES et al., 2000). The successional dynamics of pest species was dependent to the opportunities generated by plant conditions, instead of environmental change caused by the previously established species (ZANUNCIO et al., 1998). This reasoning is more efficient when the requirement of each pest taxon is considered with plant age characteristics.

Table 1 - Values of the alpha and beta parameters of the Beta function, the coefficient of determination of the model and the functional classification (Classif.) of operational taxonomic units (OTU seven morphospecies and four species of pest insects) occurrence based in the age of the stand of Eucalyptus urograndis.

Tabela 1 - Valores dos parâmetros alpha e beta da função Beta, coeficiente de determinação para os modelos e a classificação funcional (Classif.) da ocorrência das unidades taxonômicas operacionais (UTO sete morfoespécies e quatro espécies de insetos praga) baseada na idade do talhão de Eucalyptus urograndis.

\begin{tabular}{|c|c|c|c|c|c|c|}
\hline Order & Family & Species & Alpha & Beta & $\mathrm{R}^{2}$ & Classif. \\
\hline \multirow[t]{5}{*}{ Coleoptera } & Chrysomelidae & Costalimaita sp. & 0.86 & 29.86 & 0.99 & Initial \\
\hline & Buprestidae & Morphospecie 1 . & 3.46 & 135.00 & 0.45 & Initial \\
\hline & & Psiloptera sp. & 2.09 & 90.65 & 0.99 & Initial \\
\hline & & Lampetis sp. & 17.53 & 356.60 & 0.92 & Initial \\
\hline & Curculionidae & Heilipodus sp. & 1.12 & 44.26 & 0.99 & Initial \\
\hline \multirow[t]{5}{*}{ Lepidoptera } & Geometridae & Sabulodes caberata & 27.36 & 89.40 & 0.44 & Middle-age \\
\hline & & Thyrinteina sp. & 1.10 & 0.86 & 0.17 & Later \\
\hline & & Glena sp. & 1.30 & 0.91 & 0.29 & Later \\
\hline & Riodinidae & Euselasia eucerus & 5.48 & 22.27 & 0.93 & Initial \\
\hline & Notodontidae & Nystalea nyseus & 7.42 & 313.00 & 0.95 & Initial \\
\hline Hemiptera & Thaumastocoridae & Thaumastocoris peregrinus & 7.90 & 12.06 & 0.99 & Middle-age \\
\hline
\end{tabular}

Revista Árvore, Viçosa-MG, v.40, n.5, p.885-892, 2016 

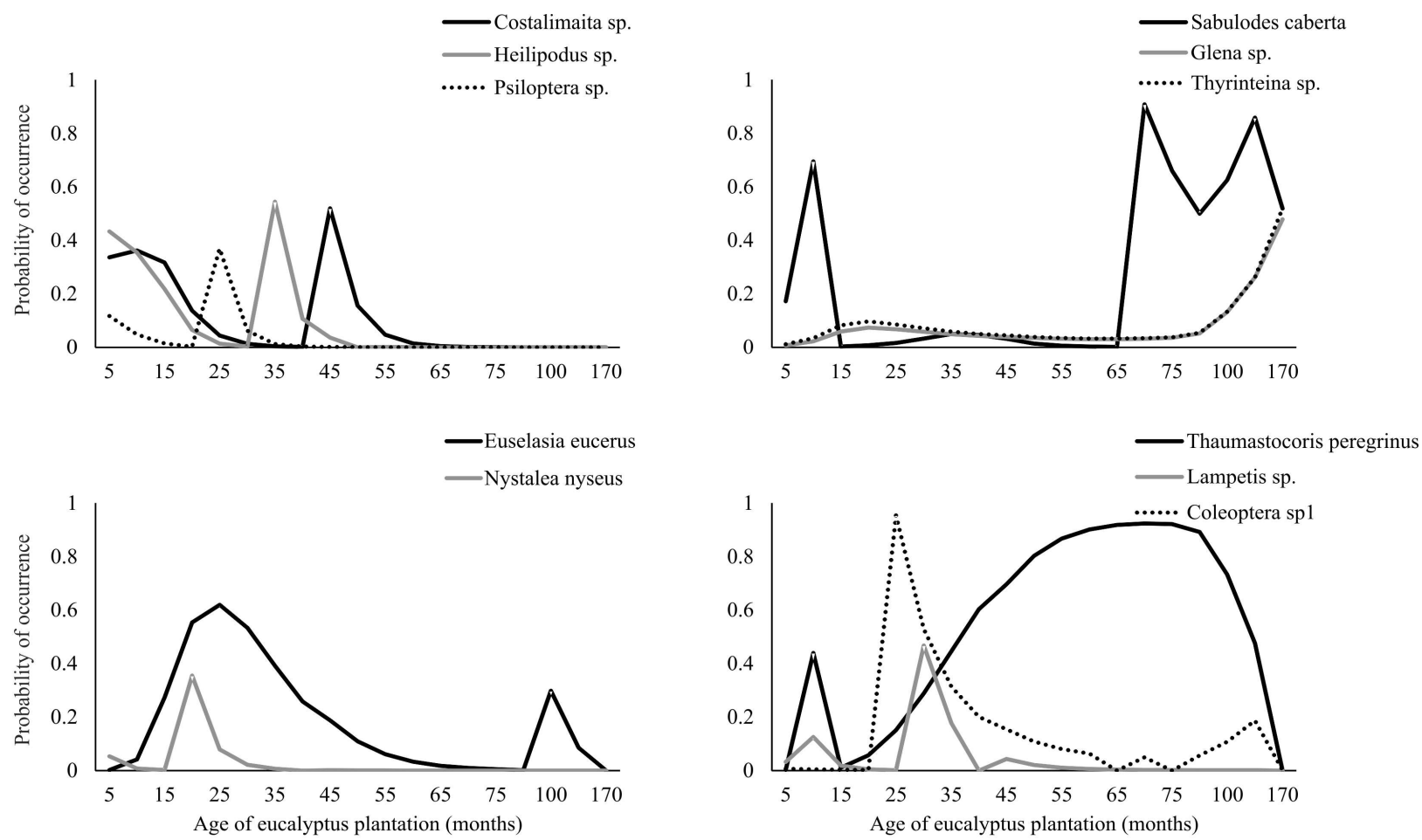

Figure 3 - Probability of occurrence related to plantation age for the operational taxonomic units (OTU, seven morphospecies and four species) of the Coleoptera, Lepidoptera and Hemiptera orders.

Figura 3 - Probabilidade de ocorrência relacionada à idade da plantação com as unidades taxonômicas operacionais (UTO sete morfoespécies e quatro espécies) das ordens Coleoptera, Lepidoptera e Hemiptera.

Costalimaita sp. and Heilipodus sp. are defoliating beetles and woodborers. Costalimaita sp. is the most important defoliator of eucalyptus in the first years of planting (LARANJEIRO, 1994). Adult Heilipodus sp. causes witches-broom of new lateral and apical branches with a loss in the final productivity (MATRANGOLO, 2010). These bionomic characteristics explain the occurrence pattern of Costalimaita sp. and Heilipodus sp. affecting mainly the initial and intermediary

Table 2 - Number of operational taxonomic units (OTU seven morphospecies and four species) within different functional classifications in regards to the occurrence period, grouped by Order.

Tabela 2 - Número de unidades taxonômicas operacionais (UTO sete morfoespécies e quatro espécies) entre diferentes classificações funcionais, baseada no período de ocorrência, agrupados por ordem.

\begin{tabular}{lccc}
\hline Order & Initial & Middle-age & Late \\
\hline Coleoptera & 5 & 0 & 0 \\
Lepidoptera & 2 & 1 & 0 \\
Hemiptera & 0 & 1 & 0 \\
\hline
\end{tabular}

development plant stages but with near-zero occurrences at late plant age. These OTU feeding on eucalyptus plants in the larval stage, when it requires early wood as a food resource.

Lampetis sp. and Psiloptera sp. are defoliating beetles that may cause considerable damage, and leafless trees respond with shoot, root and lateral branch growth, causing witches-broom Their damage was founded on adult eucalyptus plants and an adult insect can cut the main branch at two meters high of a plant (NADAI et al., 2005). However, in this study the occurrence of these two pest was elevated only in the initial development plant stages ( $<24$ months). The reduction in the probability occurrence in latter stages may be related with the occurrence of other pest, such Sabulodes caberta, specie more competitively, affecting directly or indirectly the abundance of these two OTU. However these hypotheses need to be tested in future studies.

Sabulodes caberata is a lepidopteran defoliator that consumes the leaf blade, attacks the tree from

Revista Árvore, Viçosa-MG, v.40, n.5, p.885-892, 2016 
below and affects growth by reducing the quantity of photosynthetic tissue (STRONG; LAWTON; SOUTHWOOD, 1984). This pest was more likely to occur in Eucalyptus urograndis plantations during the intermediary stage (from 65 months) but had high incidence, peaking in early stage (10 months), showing that plant age affects Lepidoptera defoliators (GUEDES et al., 2000). The peak in the early stage may be caused by the larvae of this Lepdopetera feed on leaves, and younger plants have tender leaves with less secondary defenses. The hardness of leave and concentration of chemical defenses possibly reduce, but not exclude the occurrence of $S$. caberata in more mature stages.

Thaumastocoris peregrinus had two peaks in the study, one lesser in the initial stage (10 months), and other in the intermediary and later stage. This bug is a sap-sucking and a major eucalyptus pest. This pest is more severe in the middle age stage, when the plant has a rapid leaf tissue increase, providing larger amount of food for the insect. T. peregrinus populations decline at the end of the late age stage, when chemical plant defenses and leaf production increase, and a thicker stem may be observed. However, the more soft leaves and reduced concentration of chemical defenses in the initial Eucalyptus stages may be facilitated the outbreak in the initial stage. The main damage by this species is leaf bronzing, followed by a reduction in the plant photosynthetic capacity. Such damage is observed after this bug fed leaves and thin branches to suck sap. The feeding behavior causes leaves to dry and fall, and consequently harms plant development (MENEZES et al., 2012).

\section{CONCLUSION}

The occurrence of OTU of different insect orders differed along Eucalyptus stands age. The association of the period of incidence of each OTU with plantation age reflects the resource exploration strategy of each group. Lepidoptera occurred both initially and in halflife, feeding on leaves. The Coleoptera was more frequent at early planting, once this group uses the plant during its larval stage by building galleries and feeding in early wood. The Hemiptera occurred at intermediary age because their sucking feed habit requires a large quantity of most palatable leaves. The insect pest fauna follows the eco-physiological limitations of insects in the regional assembly. The management of Eucalyptus forests must adapt to such temporal occurrence of pests species. Pest control strategies may be enhanced during the period in which they will be more effective, reaching its target more accurately.

\section{AKNOWLEDGEMENTS}

We thank Conselho Nacional de Desenvolvimento Científico e Tecnológico (CNPq) for granting a scholarship to Andrade, Celulose Nipo-Brasileira (CENIBRA) for providing the data and the Universidade Federal do Pará for financial aid (process 01/2014 PROPESP/FADESP).

\section{REFERENCES}

\section{ASSOCIAÇÃO BRASILEIRA DE FLORESTAS PLANTADAS - ABRAF. Anuário Estatístico da ABRAF. 2011.}

AGOSTA, S.J. On ecological fitting, plant-insect associations, herbivore host shifts, and host plant selection. Oikos, v. 114, n.3, p.556-565, 2006.

ANDRADE, H.A.; KINAS, P.G. Inferência em ecologia. Atlântica, v.30, n.2, p.147-160, 2008.

BERTI-FILHO. Insetos associados a plantações de espécies do gênero Eucalyptus nos Estados da Bahia, Espírito Santo, Mato Grosso do Sul, Minas Gerais e São Paulo. 1981. 177f. Tese (Livre Docência) - Escola Superior de Agricultura "Luiz de Queiroz", Universidade de São Paulo, São Paulo, 1981.

BRAGANÇA, M.A.L.; De SOUZA, O.; ZANUNCIO, J.C. Environmental heterogeneity as a strategy for pest management in Eucalyptus plantations. Forest Ecology and Management, v.102, p.9-12, 1998.

CLARK, D.A.; CLARK, D.B. Spacing dynamics of a tropical rain forest tree: evaluation of the Janzen-Connell model. The American Naturalist, v.124, n.6, p.769-788, 1984.

CONNELL, J.H. On the role of natural enemies in preventing competitive exclusion in some marine animals and in rain forest trees. In: DEN BOER, P.J.; GRADWELL, G.R. (Eds.). Dynamics of numbers in populations. Proceedings of the Advanced Study Institute, Pudoc, 1971.p.298-312. 
CORNELL, H.V.; HAWKINS, B.A. Herbivore

responses to plant secondary compounds: a test of phytochemical coevolution theory. The

American Naturalist, v.161, p.507-522, 2003.

LEITÃO FILHO, H.F. Considerações sobre a florística de florestas tropicais e subtropicais do Brasil. Campinas: IPEF, 1987.

FINLAYSON, B.; MCMAHON, T.A. Updated world map of Köppen-Geiger climate calssification.

Hydrological and Earth System

Science, v.11, p.1633-1644, 2007.

FOWLER, S.V.; LAWTON, J.H. Rapidly induced defenses and talking trees: the Devil's advocate position. The American Naturalist, v.126, n.2, p.181-195, 1985.

GELMAN, A.; CARLIN, J.; STERN, S.H.; RUBIN, D. Bayesian data analysis. London: Chapman \& Hall, 2003. 690 p.

GUREVITCH, J.; SCHNEIDER, S.; FOX, G. Ecologia vegetal. 2.ed. Porto Alegre: Artmed, 2009.

GUEDES, R.N.C.; ZANUNCIO, T.V.; ZANUNCIO, J.C.; MEDEIROS, A.G.B. Species richness and fluctuation of defoliator Lepidoptera populations in Brazilian plantations of Eucalyptus grandis as affected by plant age and weather factors. Forest Ecology and Management, v.137, p.179-184, 2000.

HOLTZ, A.M.; OLIVEIRA, H.G.; PALLINI, A.; VENZON, M.; ZANUNCIO, J.C.; OLIVEIRA, C.L.; MARINHO, J.S.; ROSADO, M.C. Desempenho de Thyrinteina arnobia Stoll (Lepidoptera:

Geometridae) em eucalipto e goiaba: o hospedeiro nativo não e um bom hospedeiro? Neotropical Entomology, v.32, p.427-431, 2003.

INMET. Normais climatológicas do Brasil. Available in: <http://www.inmet.gob.br. Accessed in Aug. 2011.

JANZEN, D.H. Herbivores and the number of tree species in tropical forests. The American Naturalist, v.104, p.940-501, 1970.

KARBAN, R.; AGRAWAL, A.A.; THALER, J.S.; ADLER, L.S. Induced plant responses and information content about risk of herbivory.
Trends in Ecology and Evolution, v. 14, p.443-447, 1999.

LARANJEIRO, A.J. Integrated pest management at Aracruz Celulose. Forest Ecology and Management, v. 65, v.1, p.45-52, 1994 .

MATRANGOLO, C. Dimorfismo sexual em Heliopodus naevulus (Mann.) (Col.: Curculionidae) e impacto do ataque no desenvolvimento inicial de clones de eucalipto. 2010. $141 \mathrm{f}$. Tese (Doutorado em Entomologia) - Universidade Federal de Viçosa, Viçosa, MG, 2010.

MENEZES, C.W.D.; SOARES, M.A.; ASSISJÚNIOR, S.L.; FONSECA, A.J.; PIRES, E.M.; SANTOS, J.B. Novos insetos sugadores (Hemiptera) atacando Eucalyptus cloeziana (Myrtacea) em Minas Gerais, Brasil.

EntomoBrasilis, v.5, n.3, p.246-248, 2012.

NADAI, J.; ANJOS, N.; SOUZA, R.M.; DINIZ, R.; CORDEIRO, G. Ocorrência de Lampetis instabillis (Castelnau \& Gory) e L. roseocarinata (Thomson)

(Coleoptera: Buprestidae) em eucalipto. 2005. [acessado em: $12 \mathrm{de} \mathrm{mar}$ 2015]. http://www.insecta.ufv.br/norivaldo/ popups/buprestidae/janaina-ocorrencialampetis-instabilis-roseocarinata.pdf.

PAULINO, C.; TURKMAN, M.; MURTEIRA, B. Estatística Bayesiana. Lisboa: Fundação Caloustre Gulbenkian, 2003.

PEREIRA, F.F., ZANUNCIO, J.C., TAVARES, M.T., PASTORI, P., JACQUES, G.C., VILELA, E.F. New record of Trichospilus diatraeae as parasitoid of the eucalypt defoliator Thyrinteina arnobia in Brasil.

Phytoparasitica, v.36, p.304-306, 2008.

SANTOS, G.; ZANUNCIO, J.C.; ZANUNCIO, T.V. Pragas do eucalipto. Informe Agropecuário, v. 18, p.63-71, 1996.

SIVA-JOTHY, M.T.; TSUBAKI, Y.; ROWAN, E.H.; PLAISTOW, S.J. Investment in immune function under chronic and acute immune challenge in an insect. Physiological Entomology, v.26, n.1, p.1-5, 2001 .

Revista Árvore, Viçosa-MG, v.40, n.5, p.885-892, 2016 
SOUTHWOOD, T.R.E. Habitat, the templet for ecological strategies? The Journal of Animal Ecology, v.46, n.2, p.337-365, 1977.

STRONG, D.; LAWTON, J.; SOUTHWOOD, S. Insects on plants. Community patterns and mechanisms.

Massachusetts: Harvard University Press, 1984. 313p.

SUTTON, S.; COLLINS, N. Insects and tropical forest conservation. In: COLLINS, N.; THOMAS, J. (Eds.). The conservation of insects and their habitats. London: Academic Press, 1991. p.405-424.

TRUGILHO, P.; LIMA, J.; MENDES, L. Influência da idade nas características físico-químicas e anatômicas da madeira de Eucalyptus saligna. Cerne, v.2, p.1-15, 2009.

VALENCIA, A.; ATKINSON, T. Scolytidae y Platypodidae (Coleoptera) de escarcega, Campeche, México. Biogeografia, biología, importancia economica y una lista comentada de especies. Anales del Instituto de Biologia, Universidad Nacional Autónoma de México: Seríe Zoología, v.58, p.199-220, 1987.

WILSON, K.; BJORNSTAD, O.; DOBSON, A. Heterogeneities in macroparasite infectious: patterns and process. In: HUDSON, P.J., RIZZOLI, A.; GRENFELL, B.T.; HEESTERBEEK, H.; DOBSON, A.P. (Eds.). The ecology of wildlife diseases. Oxford: Oxford University Press, 2002. p.6-44.
ZANUNCIO, J.C.; SANTOS, G.P.; SARTORIO, R.C.; ANJOS, N.; MATINS, L.C.C. Levantamento e flutuação populacional de lepidópteros associados à eucalipto-cultura: 3 - Região do Alto São Francisco, Minas Gerais, Março de 1988 a fevereiro de 1989. IPEF, v.41/42, p.77-82, 1989.

ZANUNCIO, J.C.; ALVES, J.B.; SANTOS, G.P.; CAMPOS, W.O. Levantamento e flutuação populacional de lepidópteros associados à eucaliptocultura: VI- Região de Belo Oriente, Minas Gerais. Pesquisa Agropecuária Brasileira, v.28, p.1121-1127,1993a.

ZANUNCIO, J.C.; SANTANA, D.L.Q.; NASCIMENTO, E.C.; SANTOS, G.P.; ALVES, J.B. Manual de pragas em florestas-Lepidoptera desfolhadoras de eucalipto: biologia, ecologia e controle. Piracicaba: Instituto de Pesquisas e Estudos Florestais-IPEF, 1993b. 140p.

ZANUNCIO, T.V.; ZANUNCIO, J.C.; MIRANDA, M.M.M.; MEDEIROS, A.G.B. Effect of plantation age on diversity and population fluctuation of Lepidoptera collected in Eucalyptus plantations in Brazil. Forest Ecology and Management, v.108, p.91-98, 1998.

ZANUNCIO, J.C.; TORRES, J.B.; SEDIYAMA, C.A.Z.; PEREIRA, F.F.; PASTORI, P.L.;

WERMELINGER, E.D.; RAMALHO, F.S. Mortality of the defoliator Euselasia eucerus (Lepidoptera: Riodinidae) by biotic factors in an Eucalyptus urophylla plantation in Minas Gerais State, Brazil. Anais da Academia Brasileira de Ciencias, v.81, p.61-66, 2009. 